\title{
Role of exogenous-applied salicylic acid, zinc and glycine betaine to improve drought- tolerance in wheat during reproductive growth stages
}

\author{
Ramadan Shemi ${ }^{1,2^{*}}$, Rui Wang ${ }^{1}$, El-Sayed M. S. Gheith², Hafiz Athar Hussain³ ${ }^{3}$ Linna Cholidah', \\ Kangping Zhang ${ }^{1}$, Sai Zhang ${ }^{1}$ and Longchang Wang ${ }^{1 *}$
}

\begin{abstract}
Background: Drought has become a dangerous threat to reduce crop productivity throughout the world. Exogenous applications of regulators, micronutrients, and/or osmoprotectants for inducing drought-tolerance in field crops have been effectively adopted. A controlled pot study was performed to investigate the relative efficacy of salicylic acid (SA), zinc (Zn), and glycine betaine (GB) as foliar applications on the growth, tissues pigments content, relative water content (RWC), leaf gas-exchange, antioxidant enzymes activity, reactive oxygen species (ROS) accumulation, osmolytes contents, and the yield parameters of wheat plants subjected to two soil water conditions (85\% field capacity: well-watered, 50\% field capacity: water-deficient) during reproductive growth stages.

Results: Water deficient conditions significantly decreased the growth, yield parameters, RWC, photosynthesis pigment, and gas-exchange attributes except for intercellular $\mathrm{CO}_{2}$ concentration. However, foliar applications remarkably improved the growth and yield parameters under water deficit conditions. Under drought condition, exogenous applications of SA, Zn, and GB increased the grain yield pot ${ }^{-1}$ by $27.99,15.23$ and $37.36 \%$, respectively, as compared to the control treatment. Drought stress statistically increased the contents of hydrogen peroxide $\left(\mathrm{H}_{2} \mathrm{O}_{2}\right)$, superoxide anion radical $\left(\mathrm{O}_{2}{ }^{-}\right)$, and malonaldehyde (MDA), and elevated the harmful oxidation to cell lipids in plants, however, they were considerably reduced by foliar applications. Foliar applications of SA, Zn, and GB decreased MDA content by $29.09,16.64$ and $26.51 \%$ under drought stress, respectively, as compared to the control treatment. Activities of all antioxidant enzymes, proline content, and soluble sugar were increased in response to foliar applications under water deficit conditions.

Conclusions: Overall, foliar application of GB, SA, and Zn compounds improved the drought-tolerance in wheat by decreasing the ROS accumulation, promoting enzymatic antioxidants, and increasing osmolytes accumulation. Finally, GB treatment was most effective in thoroughly assessed parameters of wheat followed by SA and Zn applications to alleviate the adverse effects of drought stress.
\end{abstract}

\footnotetext{
*Correspondence: ramadangamil@agr.cu.edu.eg; wanglc@swu.edu.cn

${ }^{1}$ College of Agronomy and Biotechnology, Southwest University,

Chongqing 400715, China

2 Department of Agronomy, Faculty of Agriculture, Cairo University,

Giza 12613, Egypt

Full list of author information is available at the end of the article
}

(C) The Author(s) 2021. Open Access This article is licensed under a Creative Commons Attribution 4.0 International License, which permits use, sharing, adaptation, distribution and reproduction in any medium or format, as long as you give appropriate credit to the original author(s) and the source, provide a link to the Creative Commons licence, and indicate if changes were made. The images or other third party material in this article are included in the article's Creative Commons licence, unless indicated otherwise in a credit line to the material. If material is not included in the article's Creative Commons licence and your intended use is not permitted by statutory regulation or exceeds the permitted use, you will need to obtain permission directly from the copyright holder. To view a copy of this licence, visit http://creativecommons.org/licenses/by/4.0/. The Creative Commons Public Domain Dedication waiver (http://creativeco mmons.org/publicdomain/zero/1.0/) applies to the data made available in this article, unless otherwise stated in a credit line to the data. 
Keywords: Antioxidant defense mechanisms, Drought-tolerance, Foliar applications, Oxidative stress, Wheat (Triticum aestivum L.)

\section{Background}

Wheat (Triticum aestivum L.) is one of the most important cereal crops which is highly susceptible to drought stress [1]. Universally, the wheat crop is the primary vegetable protein source in the diet of humans, containing a higher protein content than other main grain crops such as maize and rice. The increasing population and food demands further necessitate the increase in wheat production to ensure social stability and future food security $[2,3]$. In China, wheat is the second-most important food crop after rice and the third-most important crop in total production overall, after maize and rice [4]. The cultivated area of wheat in China was estimated to be 23.73 million ha and it yielded about 133.60 million metric tonnes year ${ }^{-1}$ [4]. Wheat is sensitive cereal crop to drought stress after maize, especially during the critical growth periods (e.g., flowering stage). However, drought led to the yield reduction among different species, in which maize had higher yield reduction (39.3\%) compared to wheat $(20.6 \%)$ by $40 \%$ water deficiency [5]. Drought is the most important one of abiotic stress factors that negatively influence the growth and production of various field crops [6-10]. Drought causes various changes in crop plants through different morphological, physiological, and biochemical responses [11-13]. Many studies have reported that the defense system of antioxidant was increased through the synthesis of antioxidants such as ascorbate peroxidase (APX) and glutathione reductase (GR), and enzymatic antioxidants such as peroxidase (POD), catalase (CAT), and superoxide dismutase (SOD), which were stimulated to quench the ROS production in plants during drought stress [3, 6, 14-16]. Moreover, Datir et al. [17] have reported that the antioxidant enzymes, free proline contents, GB accumulation, MDA, and $\mathrm{H}_{2} \mathrm{O}_{2}$ contents were increased under drought induced by polyethylene glycol (PEG) in wheat cultivars. In addition, Chen et al. [18] remarked that the drought stress slowed down wheat growth and reduced grain yield by impacting the anthesis and grain-filling process, and decreased leaf water potential, stomatal conductance, and the photosynthesis.

Foliar applications of various growth regulators, micronutrients, and osmoprotectants can play the key role in inducing drought-tolerance in plants at various plant growth stages [10, 19-22]. SA is a multifunctional plant hormone that can effectively ameliorate the adverse effects caused by biotic and abiotic stresses [23-26] by modulating different growth responses, and physiological and biochemical characteristics in plants [10, 27-30]. A useful role of the salicylic acid has been noticed in improving drought stress tolerance in wheat by improving the relative water contents, leaf gas-exchange, soluble carbohydrate, proteins, proline contents, the activity of antioxidant enzymes and yield attributes [21, 31, 32]. Furthermore, Zinc is an essential micronutrient that participates in many physiological functions and structure of the regulatory cofactor of many enzymes, carbohydrate, chlorophyll production, pollen function, fertilization, metabolism of RNA, protein synthesis, and the DNA functions [33, 34]. Water deficit condition at grain filling phase statistically reduced the plant height, yield parameters, RWC, chlorophyll contents, and decreased activity of SOD, POD, and CAT, while exogenous applications of zinc and salicylic acid had positive impact on all these parameters and mitigated the harmful effects of water deficit on wheat plants [20,31,35]. Rahmani et al. [36] reported that supplemental $\mathrm{Zn}$ improved the droughttolerance in safflower by increasing proline, relative water content, chlorophyll contents, and the yield and its components. Nevertheless, GB has an important role as an osmoprotectants, which help the plants to resist drought through improved leaf gas-exchange and chlorophyll content in maize plants [37]. Wheat genotypes prevent the damage of PEG induced osmotic stress via various mechanisms such as osmolytes accumulation [38]. In addition, net photosynthesis, transpiration rate, and yield attributes were decreased under drought stress at the tillering, flowering, and milking stages in wheat plants, while exogenous application of GB enhanced them under drought treatment [19, 39]. Similarly, Hasanuzzaman et al. [40] recorded that GB played an important role in reducing aggregation and detoxification of ROS, hence recovering photosynthesis and decreasing oxidative stress. Our previous study, Shemi et al. [22] have illustrated that exogenous applications of GB, $\mathrm{Zn}$, and SA substantially improved the activity of CAT, SOD, and APX enzymes, and decreased the contents of MDA and $\mathrm{H}_{2} \mathrm{O}_{2}$, and these changes were beneficial to protect maize leaf tissues from oxidative harm in cell membranes.

However, there is no investigation has been carried out to assess the relative effects of SA, Zn, or GB compounds in inducing drought-tolerance of the wheat crop during reproductive growth stages. The current study was aimed to test the hypothesis that the foliar applications of salicylic acid, zinc, and/or glycine betaine can ameliorate the damaging effects of drought 
stress in wheat during reproductive growth stages by observing the changes in the scavenging ability of antioxidant defense system, which constitutes the executive for the protective response system. The objectives of the study were to (1) Investigate the response of wheat growth, yield, and its attributes to the exogenous applications of SA, Zn, and GB under different soil water conditions during reproductive growth stages; (2) Determine the effect of respective exogenous applications on chlorophyll contents, RWC, leaf gas-exchange, antioxidant enzymes activity, MDA content, and ROS and osmolytes accumulations under different soil water conditions; and (3) Compare the efficacy of concerned exogenous applications to alleviate the harmful effects of drought stress under different soil water conditions.

\section{Results}

Growth and yield attributes

Water deficient condition statistically $(p<0.05)$ hampered the wheat growth and yield parameters in terms of plant height, fresh weight of plants pot ${ }^{-1}$, dry weight of plants pot $^{-1}$, leaf area of plants pot ${ }^{-1}$, number of tillers pot $^{-1}$, number of spikes pot ${ }^{-1}$, number of grains spike ${ }^{-1}$, grain weight spike ${ }^{-1}, 1000$-grain weight, biological yield pot $^{-1}$, grain yield pot ${ }^{-1}$, and harvest index in comparison to well-watered condition. However, results showed that growth and yield parameters were improved by SA, $\mathrm{Zn}$, and GB spraying treatments in both stressed and non-stressed plants (Tables 1, 2, and 3). As expected, one or more spraying treatments significantly enhanced all parameters in both soil water conditions except for the number of grains spike ${ }^{-1}$ as compared to the control. The respective spraying treatments increased plant height

Table 1 Influences of soil water conditions and foliar treatments on wheat growth parameters

\begin{tabular}{|c|c|c|c|c|c|c|c|}
\hline $\begin{array}{l}\text { Soil } \\
\text { water } \\
\text { conditions }\end{array}$ & Foliar treatments & $\begin{array}{l}\text { Plant } \\
\text { height } \\
\text { (cm) }\end{array}$ & $\begin{array}{l}\text { Fresh weight of } \\
\text { plants pot } \\
\text { (g) }\end{array}$ & $\begin{array}{l}\text { Dry weight of } \\
\text { plants pot } \\
\text { (g) }\end{array}$ & $\begin{array}{l}\text { Leaf area of } \\
\text { plants pot } \\
\left(\mathrm{cm}^{2}\right)\end{array}$ & $\begin{array}{l}\text { No. } \\
\text { of tillers } \\
\text { pot }^{-1}\end{array}$ & $\begin{array}{l}\text { No. } \\
\text { of spikes } \\
\text { pot }^{-1}\end{array}$ \\
\hline \multirow[t]{5}{*}{ ww } & CK & $63.39^{b c} \pm 1.67$ & $73.13^{b c} \pm 2.92$ & $17.79^{d} \pm 0.73$ & $962.74^{\complement} \pm 54.55$ & $18.62^{\complement} \pm 0.56$ & $16.67^{b} \pm 0.33$ \\
\hline & SA & $70.58^{a} \pm 1.40$ & $81.20^{\mathrm{a}} \pm 3.31$ & $21.95^{b} \pm 0.61$ & $1067.01^{b} \pm 61.24$ & $20.59^{\mathrm{ab}} \pm 0.55$ & $18.34^{\mathrm{a}} \pm 0.61$ \\
\hline & $\mathrm{Zn}$ & $68.67^{\mathrm{ab}} \pm 2.64$ & $79.48^{\mathrm{ab}} \pm 3.62$ & $20.73^{b c} \pm 0.73$ & $1015.75^{\mathrm{bc}} \pm 53.79$ & $19.83^{b} \pm 0.60$ & $17.83^{b} \pm 0.33$ \\
\hline & GB & $71.86^{\mathrm{a}} \pm 2.71$ & $82.38^{\mathrm{a}} \pm 4.11$ & $23.57^{\mathrm{a}} \pm 0.94$ & $1148.27^{\mathrm{a}} \pm 65.15$ & $21.27^{\mathrm{a}} \pm 0.79$ & $19.00^{\mathrm{a}} \pm 0.34$ \\
\hline & Means & 68.62 & 79.05 & 21.00 & 1048.44 & 20.07 & 17.96 \\
\hline \multirow[t]{5}{*}{ WD } & CK & $57.73^{\mathrm{d}} \pm 0.70$ & $43.16^{f} \pm 2.38$ & $14.66^{f} \pm 0.15$ & $428.14^{f} \pm 21.73$ & $14.38^{f} \pm 0.61$ & $12.55^{d} \pm 0.65$ \\
\hline & SA & $61.74^{c} \pm 0.59$ & $51.31^{d} \pm 2.04$ & $16.98^{\mathrm{e}} \pm 0.30$ & $596.60^{\text {de }} \pm 23.37$ & $16.26^{d} \pm 0.53$ & $14.28^{c} \pm 0.72$ \\
\hline & $\mathrm{Zn}$ & $61.73^{c} \pm 0.33$ & $48.04^{\mathrm{de}} \pm 2.57$ & $16.03^{e} \pm 0.72$ & $570.37^{e} \pm 27.85$ & $15.67^{\mathrm{de}} \pm 0.41$ & $13.77^{c} \pm 0.63$ \\
\hline & GB & $62.38^{b c} \pm 1.70$ & $53.16^{d} \pm 2.10$ & $18.81^{d} \pm 0.35$ & $632.10^{d} \pm 16.41$ & $16.58^{d} \pm 0.44$ & $14.60^{\complement} \pm 0.47$ \\
\hline & Means & 60.89 & 48.92 & 16.61 & 556.80 & 15.72 & 13.79 \\
\hline
\end{tabular}

Values are means ( $\pm \mathrm{SE}$ ) of three replicates. For L.S.D.s results, means with various letters indicate the significant differences $(p<0.05)$. $W W$ well-watered; $W D$ waterdeficient; $C K$ control (double distilled water); $S A$ salicylic acid; $Z n$ zinc; $G B$ glycine betaine

Table 2 Influences of soil water conditions and foliar treatments on wheat yield and its components

\begin{tabular}{|c|c|c|c|c|c|c|c|}
\hline $\begin{array}{l}\text { Soil } \\
\text { water } \\
\text { conditions }\end{array}$ & Foliar treatments & $\begin{array}{l}\text { No. } \\
\text { of grainsspike }{ }^{-1}\end{array}$ & $\begin{array}{l}\text { Grain weight } \\
\text { spike }^{-1} \\
\text { (g) }\end{array}$ & $\begin{array}{l}\text { 1000-grain } \\
\text { weight } \\
\text { (g) }\end{array}$ & $\begin{array}{l}\text { Biological yield } \\
\text { pot }^{-1} \\
\text { (g) }\end{array}$ & $\begin{array}{l}\text { Grain yield pot }{ }^{-1} \\
\text { (g) }\end{array}$ & $\begin{array}{l}\text { Harvest } \\
\text { index } \\
(\%)\end{array}$ \\
\hline \multirow[t]{5}{*}{ ww } & CK & $38.12^{\mathrm{a}} \pm 0.97$ & $1.48^{\mathrm{bc}} \pm 0.03$ & $38.97^{b c} \pm 0.93$ & $58.93^{\mathrm{cd}} \pm 0.73$ & $22.77^{\mathrm{cd}} \pm 0.73$ & $38.58^{b} \pm 2.33$ \\
\hline & SA & $41.40^{\mathrm{a}} \pm 0.99$ & $1.73^{\mathrm{ab}} \pm 0.07$ & $41.64^{\mathrm{ab}} \pm 0.76$ & $67.80^{\mathrm{ab}} \pm 2.67$ & $27.28^{\mathrm{ab}} \pm 0.83$ & $40.46^{\mathrm{ab}} \pm 2.82$ \\
\hline & $\mathrm{Zn}$ & $39.42^{\mathrm{a}} \pm 1.41$ & $1.57^{\mathrm{b}} \pm 0.03$ & $39.89^{b} \pm 0.85$ & $66.32^{b c} \pm 3.41$ & $25.42^{b c} \pm 0.24$ & $38.62^{b} \pm 0.80$ \\
\hline & GB & $42.02^{\mathrm{a}} \pm 1.71$ & $1.78^{\mathrm{a}} \pm 0.03$ & $42.52^{\mathrm{a}} \pm 1.65$ & $70.33^{\mathrm{a}} \pm 2.61$ & $29.24^{a} \pm 0.77$ & $41.70^{a} \pm 2.01$ \\
\hline & Means & 40.23 & 1.64 & 40.75 & 65.84 & 26.18 & 39.83 \\
\hline \multirow[t]{5}{*}{ WD } & CK & $35.69^{\mathrm{a}} \pm 1.32$ & $1.14^{\mathrm{e}} \pm 0.04$ & $31.87^{f} \pm 0.23$ & $43.16^{9} \pm 0.88$ & $15.36^{f} \pm 0.29$ & $35.60^{c d} \pm 0.74$ \\
\hline & SA & $36.93^{\mathrm{a}} \pm 1.05$ & $1.29^{c d} \pm 0.06$ & $34.98^{\mathrm{d}} \pm 1.08$ & $50.77^{\mathrm{e}} \pm 1.71$ & $19.66^{\mathrm{de}} \pm 0.34$ & $38.80^{b} \pm 1.20$ \\
\hline & $\mathrm{Zn}$ & $36.13^{\mathrm{a}} \pm 0.54$ & $1.20^{\mathrm{de}} \pm 0.04$ & $33.24^{\mathrm{ef}} \pm 1.39$ & $48.75^{\mathrm{ef}} \pm 1.39$ & $17.70^{e} \pm 0.69$ & $36.30^{c} \pm 1.07$ \\
\hline & GB & $37.46^{\mathrm{a}} \pm 1.12$ & $1.35^{\mathrm{C}} \pm 0.03$ & $36.15^{\mathrm{cd}} \pm 0.39$ & $54.02^{\text {de }} \pm 2.22$ & $21.10^{d} \pm 0.53$ & $39.16^{\mathrm{ab}} \pm 1.50$ \\
\hline & Means & 36.55 & 1.24 & 34.05 & 49.17 & 18.45 & 37.46 \\
\hline
\end{tabular}

Values are means $( \pm \mathrm{SE})$ of three replicates. For L.S.D.'s results, means with various letters indicate the significant differences $(p<0.05)$. $W W$ well-watered; $W D$ waterdeficient; $C K$ control (double distilled water); $S A$ salicylic acid; $Z n$ zinc; GB glycine betaine 
Table $3 p$-values of the two-way factorial analysis of growth, yield, and physiological and biochemical parameters of wheat as affected by various foliar treatments under both soil water conditions

\begin{tabular}{|c|c|c|c|}
\hline \multirow[t]{2}{*}{ Parameters } & \multicolumn{2}{|c|}{$\begin{array}{l}\text { Main factors } \\
\text { effects }\end{array}$} & \multirow{2}{*}{$\begin{array}{l}\text { Interaction effects } \\
S \times F\end{array}$} \\
\hline & $S$ & $\mathrm{~F}$ & \\
\hline Plant height & $<0.0001$ & $<0.0065$ & $<0.0392$ \\
\hline Fresh weight of plants & $<0.0001$ & $<0.0249$ & $<0.0486$ \\
\hline Dry weight of plants & $<0.0001$ & $<0.0001$ & $<0.0372$ \\
\hline Leaf area of plants & $<0.0001$ & $<0.0038$ & $<0.0435$ \\
\hline Number of tillers & $<0.0001$ & $<0.0037$ & $<0.0467$ \\
\hline Number of spikes & $<0.0001$ & $<0.0051$ & $<0.0245$ \\
\hline Number of grains & $<0.0004$ & $<0.1066$ & $<0.4751$ \\
\hline Grain weight & $<0.0001$ & $<0.0001$ & $<0.0371$ \\
\hline 1000 -grain weight & $<0.0001$ & $<0.0061$ & $<0.0497$ \\
\hline Biological yield & $<0.0001$ & $<0.0007$ & $<0.0378$ \\
\hline Grain yield & $<0.0001$ & $<0.0001$ & $<0.0212$ \\
\hline Harvest index & $<0.0073$ & $<0.0054$ & $<0.0485$ \\
\hline Chlorophyll a content & $<0.0087$ & $<0.0019$ & $<0.0347$ \\
\hline Chlorophyll b content & $<0.0180$ & $<0.0097$ & $<0.0492$ \\
\hline Total chlorophyll content & $<0.0163$ & $<0.0010$ & $<0.0345$ \\
\hline RWC & $<0.0001$ & $<0.0273$ & $<0.0479$ \\
\hline Net photosynthesis rate & $<0.0001$ & $<0.0003$ & $<0.0198$ \\
\hline Transpiration rate & $<0.0001$ & $<0.0008$ & $<0.0245$ \\
\hline Stomatal conductance & $<0.0001$ & $<0.0001$ & $<0.0359$ \\
\hline $\begin{array}{l}\text { Intercellular } \mathrm{CO}_{2} \text { concentra- } \\
\text { tion }\end{array}$ & $<0.0100$ & $<0.0204$ & $<0.0457$ \\
\hline APX activity & $<0.0001$ & $<0.0002$ & $<0.0021$ \\
\hline GR activity & $<0.0001$ & $<0.0002$ & $<0.0102$ \\
\hline POD activity & $<0.0001$ & $<0.0001$ & $<0.0260$ \\
\hline CAT activity & $<0.0001$ & $<0.0001$ & $<0.0002$ \\
\hline SOD activity & $<0.0001$ & $<0.0001$ & $<0.0302$ \\
\hline MDA content & $<0.0001$ & $<0.0001$ & $<0.0430$ \\
\hline $\mathrm{H}_{2} \mathrm{O}_{2}$ content & $<0.0001$ & $<0.0001$ & $<0.0469$ \\
\hline $\mathrm{O}_{2}^{--}$content & $<0.0001$ & $<0.0001$ & $<0.0041$ \\
\hline Free proline content & $<0.0001$ & $<0.0001$ & $<0.0006$ \\
\hline Total soluble sugar & $<0.0001$ & $<0.0001$ & $<0.0019$ \\
\hline
\end{tabular}

$p$-values are considered as significant $(p<0.05, n=3)$ and highly significant $(p<0.01, n=3)$. 'S': effect of soil water conditions;' $F$ ': effect of foliar treatments; 'S $\times \mathrm{F}^{\prime}$ : effect of the interaction between two variables

by $6.94,6.92$ and $8.05 \%$, fresh weight of plants pot $^{-1}$ by $18.88,11.30$ and $23.16 \%$, dry weight of plants pot $^{-1}$ by $15.82,9.34$ and $28.30 \%$, leaf area of plants pot $^{-1}$ by $39.34,33.22$ and $47.63 \%$, number of tillers pot $^{-1}$ by 13.07 , 8.97 and $15.29 \%$, number of spikes pot ${ }^{-1}$ by $13.78,9.72$ and $16.33 \%$, number of grains spike ${ }^{-1}$ by $3.47,1.23$ and $4.95 \%$, grain weight spike ${ }^{-1}$ by $13.15,2.26$ and $18.42 \%$, 1000 -grain weight by $9.75,4.29$ and $13.42 \%$, biological yield pot $^{-1}$ by $17.63,12.95$ and $25.16 \%$, grain yield pot ${ }^{-1}$ by $27.99,15.23$ and $37.36 \%$, and harvest index by 8.98 ,
1.96 and $10.00 \%$ under water-deficient condition, respectively, as compared to the values of the control treatment. Overall, maximum growth and yield parameters were recorded from the plants treated with GB followed by SA and $\mathrm{Zn}$ spraying treatments as compared with control treatment under both soil water conditions.

\section{Photosynthetic pigments and RWC}

Chlorophyll $(C h l$.) and relative water contents (RWC) of wheat leaves were significantly $(p<0.05)$ decreased by the water-deficient condition. Nevertheless, the Chl. a, Chl. $b$ and total Chl. contents and RWC were enhanced by SA, $\mathrm{Zn}$, and GB spraying treatments in both stressed and non-stressed plants (Fig. 1 and Table 3). The Chl. $a$ and total Chl. contents were significantly impacted by concerned spraying treatments under water-deficient condition, and GB spraying treatment under well-watered condition, while $C h l . b$ content was statistically affected by GB in both soil water conditions and RWC was significantly influenced by SA and GB treatments under water-deficient conditions. Under the water-deficient condition, the respective spraying treatments improved contents of Chl. $a$ by $23.91,22.82$ and $26.08 \%, C h l . b$ by $10.85,8.52$ and $13.95 \%$, total Chl . by $18.53,16.93$ and $21.40 \%$, and RWC by $18.55,6.44$ and $22.35 \%$, respectively, as compared to the values of the control treatment. Generally, the highest photosynthetic pigments and RWC were recorded from the plants treated with GB followed by $\mathrm{SA}$ and $\mathrm{Zn}$ spraying treatments as compared with the control treatment under both soil water conditions.

\section{Photosynthesis gas-exchange}

Net photosynthesis rate $(\mathrm{Pn})$, transpiration rate $(\mathrm{Tr})$, stomatal conductance (Gs), and intercellular $\mathrm{CO}_{2}$ concentration $(\mathrm{Ci})$ were statistically $(p<0.05)$ influenced by soil water conditions. However, results noticed that photosynthesis gas-exchange parameters were increased by SA, Zn, and GB spraying treatments except for $\mathrm{Ci}$ (Fig. 2 and Table 3). Pn and Tr were significantly affected by SA and GB treatments under water-deficient conditions and GB under well-watered conditions, while Gs was considerably impacted by concerned spraying treatments under both soil water conditions except for $\mathrm{Zn}$ under the well-watered condition, and $\mathrm{Ci}$ was substantially reduced by SA and GB treatments under water-deficient condition. Under the water-deficient condition, the respective spraying treatments promoted the Pn by $34.74,30.11$ and $49.03 \%$, Tr by $21.84,13.15$ and $33.42 \%$, and Gs by 58.97 , 35.89 and $69.23 \%$, while they decreased the $\mathrm{Ci}$ by 13.01 , 9.94 and $16.22 \%$, respectively, as compared to the values of the control treatment. In general, the highest Pn, $\mathrm{Tr}$, and Gs, and the lowest $\mathrm{Ci}$ were registered from the plants treated with GB followed by SA and Zn spraying 

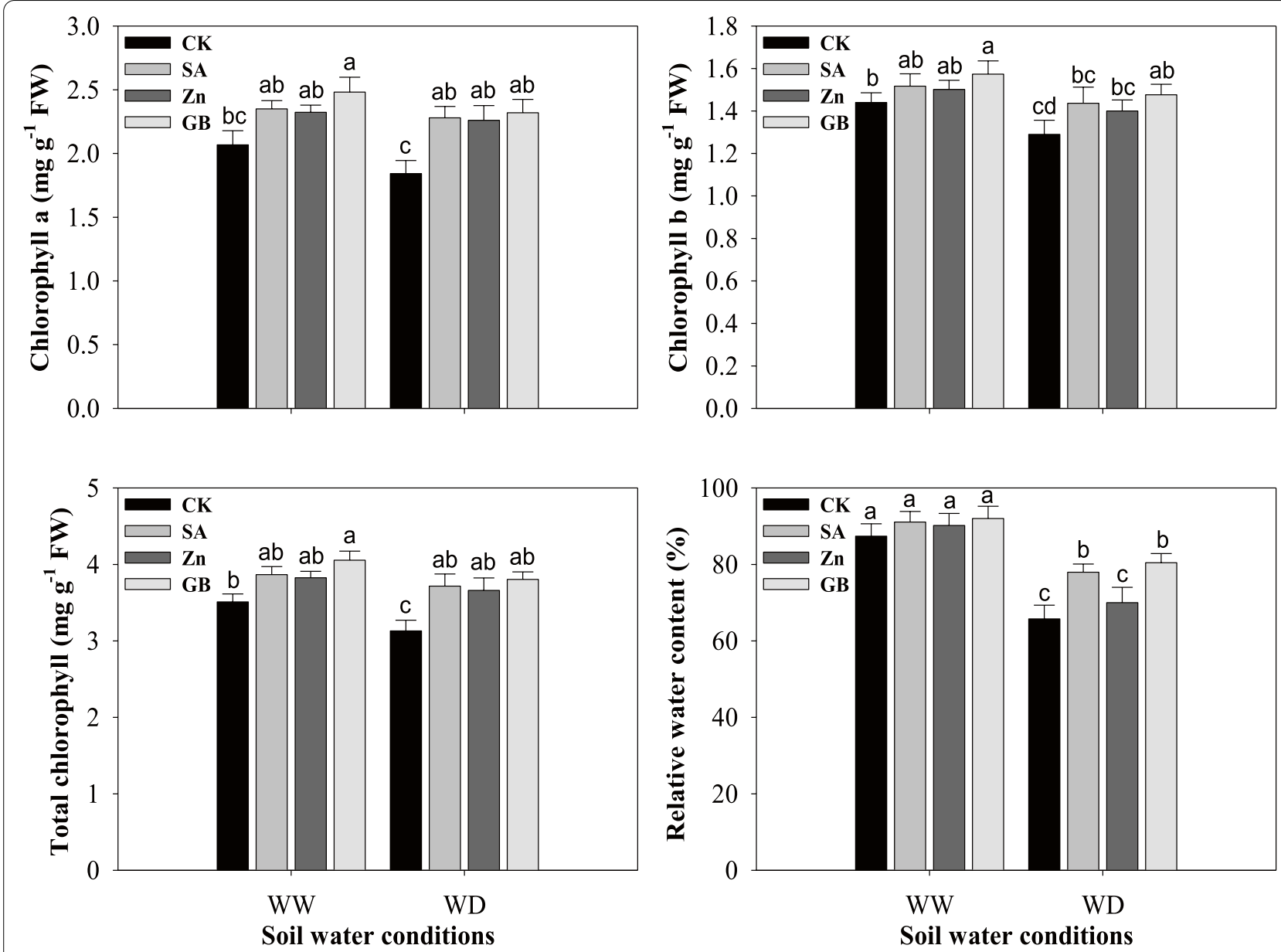

Fig. 1 Influences of soil water conditions and foliar treatments on chlorophyll a content, chlorophyll b content, total chlorophyll content and relative water content. Every column in each graph represents the mean $( \pm \mathrm{SE})$ of three replicates. Various letters above columns indicate the significant differences among means $(p<0.05)$. WW, well-watered; WD, water-deficient; $C K$, control (double distilled water); SA, salicylic acid; Zn, zinc; GB, glycine betaine

treatments as compared with control treatment under both soil water conditions.

\section{Enzymatic antioxidants and MDA content}

APX, GR, POD, CAT, and SOD activities, and MDA content were significantly $(p<0.05)$ affected by soil water conditions. Results indicated that APX, GR, POD, CAT, and SOD activities were increased and MDA content was decreased by SA, Zn, and GB spraying treatments in both stressed and non-stressed plants (Fig. 3 and Table 3). GR and CAT activities and MDA contents were statistically impacted by concerned spraying treatments in both soil water conditions except for Zn under well-watered condition; while APX, POD, and SOD activities were significantly influenced by concerned spraying treatments under water-deficient condition, and POD by GB application and SOD by SA application under well-watered condition. Under the water-deficient condition, the respective spraying treatments improved the activity of APX by $47.82,29.89$ and $42.39 \%$, GR by $59.62,42.85$ and $48.44 \%$, POD by $26.08,18.84$ and $35.30 \%$, CAT by 62.16 , 50.95 and $120.11 \%$, SOD by $61.42,34.64$ and $42.20 \%$, but reduced MDA content by $29.09,16.64$ and $26.51 \%$, respectively, as compared to the values of the control treatment. Overall, the highest APX, GR, and SOD activities and the lowest MDA contents were recorded from the plants treated with SA followed by GB and Zn spraying treatments, while the highest POD and CAT activities were recorded from the plants treated with $\mathrm{GB}$ followed by SA and Zn spraying treatments as compared with control treatment under both soil water conditions.

\section{Reactive oxygen species accumulation}

The level of ROS accumulation was statistically $(p<0.05)$ increased under water-deficient conditions. Results showed that $\mathrm{H}_{2} \mathrm{O}_{2}$ and $\mathrm{O}_{2}{ }^{--}$contents were decreased 


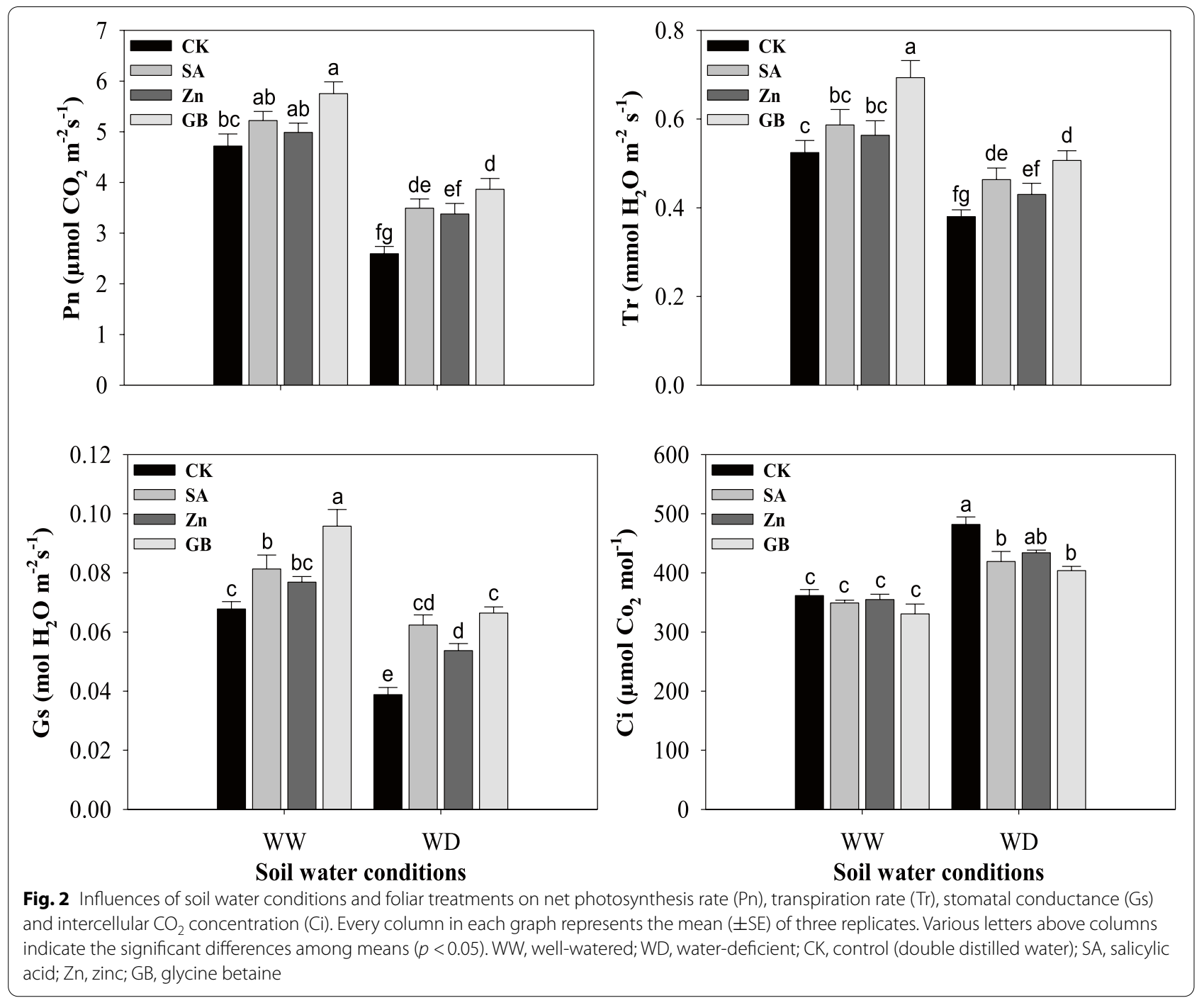

by SA, Zn, and GB spraying treatments in both stressed and non-stresses plants (Fig. 4 and Table 3). $\mathrm{H}_{2} \mathrm{O}_{2}$ and $\mathrm{O}_{2}{ }^{\cdot-}$ contents were significantly impacted by concerned spraying treatments under both soil water conditions except for $\mathrm{Zn}$ under well-watered conditions. Under the water-deficient condition, the respective spraying treatments decreased the contents of $\mathrm{H}_{2} \mathrm{O}_{2}$ by $29.33,23.99$ and $26.45 \%$, and $\mathrm{O}_{2}{ }^{--}$by $36.10,25.26$ and $28.97 \%$, respectively, as compared to the values of the control treatment. Overall, results indicated that the lowest $\mathrm{H}_{2} \mathrm{O}_{2}$ and $\mathrm{O}_{2}{ }^{\cdot-}$ contents were recorded from the plants treated with SA followed by GB and $\mathrm{Zn}$ spraying treatments as compared with control treatment under both soil water conditions.

\section{Osmolytes accumulation}

Free proline contents and total soluble sugar were significantly $(p<0.05)$ enhanced by the water-deficient condition. Results indicated that free proline contents and total soluble sugar were increased with SA, Zn, and GB spraying treatments in both stressed and nonstressed plants (Fig. 5 and Table 3). Free proline content and total soluble sugar were statistically affected by concerned spraying treatments under water-deficient conditions and GB under well-watered conditions. Under the water-deficient condition, the respective spraying treatments enhanced free proline content by $53.57,33.41$ and $67.07 \%$, and total soluble sugar by $36.01,22.76$ and $56.25 \%$, respectively, as compared to the values of the control treatment. Overall, results showed that the highest free proline and total soluble sugar contents were recorded from the plants treated with GB followed by SA and Zn spraying treatments as compared with control treatment under both soil water conditions. 

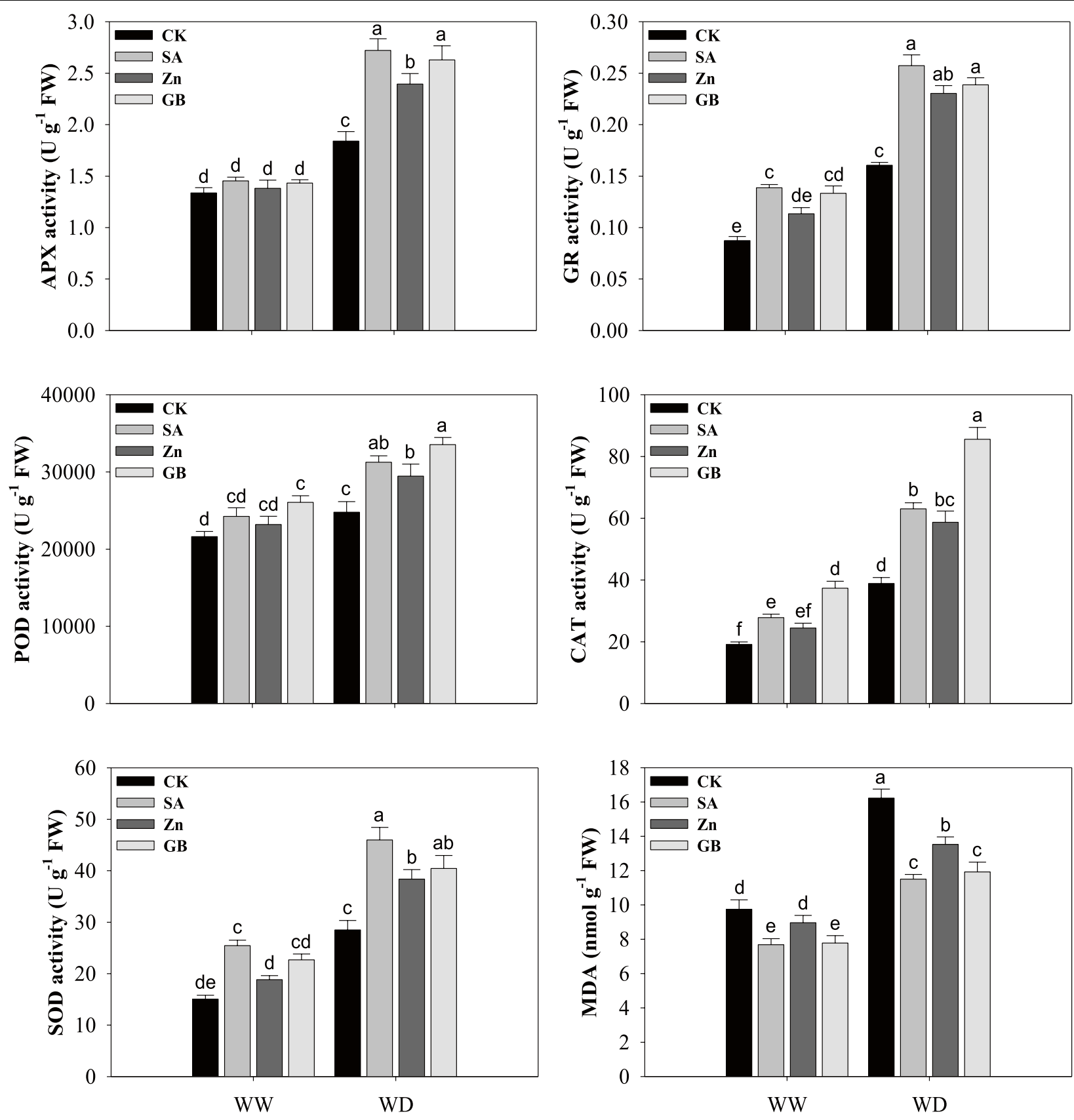

Soil water conditions

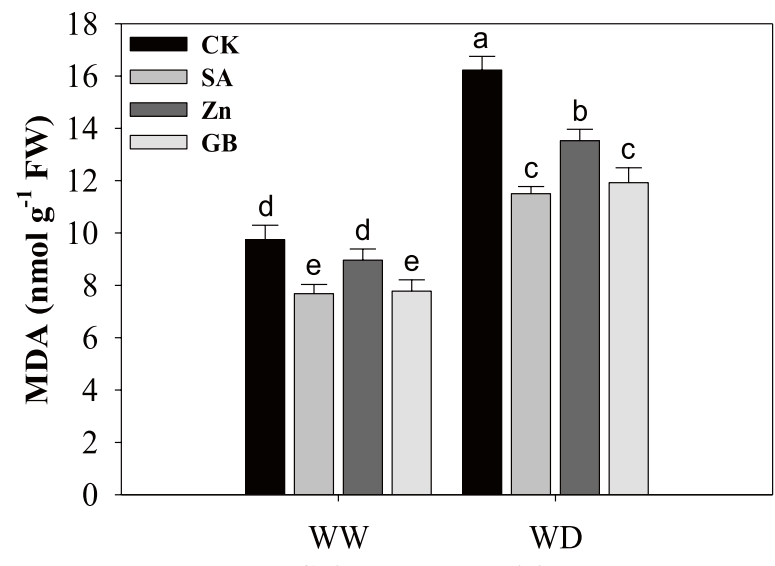

Fig. 3 Influences of soil water conditions and foliar treatments on the activities of ascorbate peroxidase (APX), glutathione reductase (GR), peroxidase (POD), catalase (CAT), superoxide dismutase (SOD) and malonaldehyde (MDA) content. Every column in each graph represents the mean ( \pm SE) of three replicates. Various letters above columns indicate the significant differences among means $(p<0.05)$. WW, well-watered; WD, water-deficient; CK, control (double distilled water); SA, salicylic acid; Zn, zinc; GB, glycine betaine

\section{Discussion}

Drought is a critical agricultural hazard that negatively influences the crop production and may cause a disequilibrium between the defense systems of antioxidant and ROS accumulation, resulting in oxidative damages [6, 8-10, 41-44]. Bayoumi et al. [45] reported that drought led to a decrease in plant height, the number of tillers, 1000-grain weight, spike length, biologi$\mathrm{cal}$ and grain yields, and harvest index. Drought stress may hinder the total growth and development of 


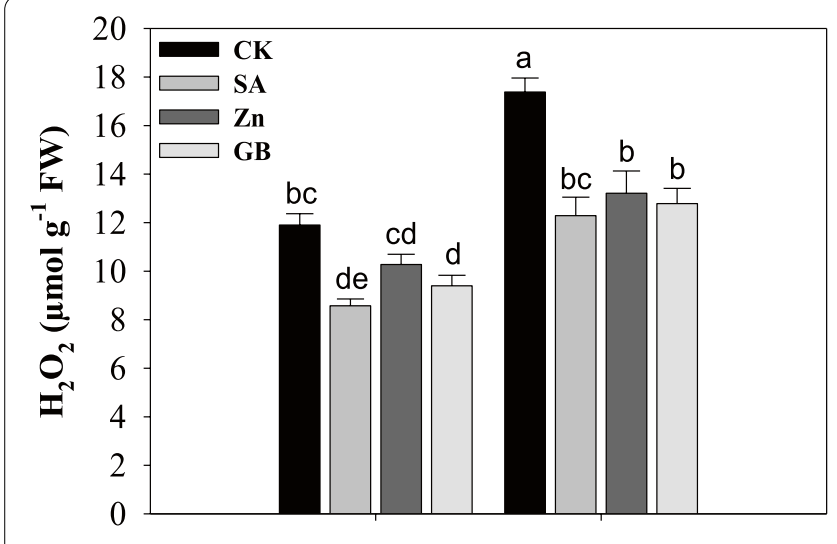

WW

WD

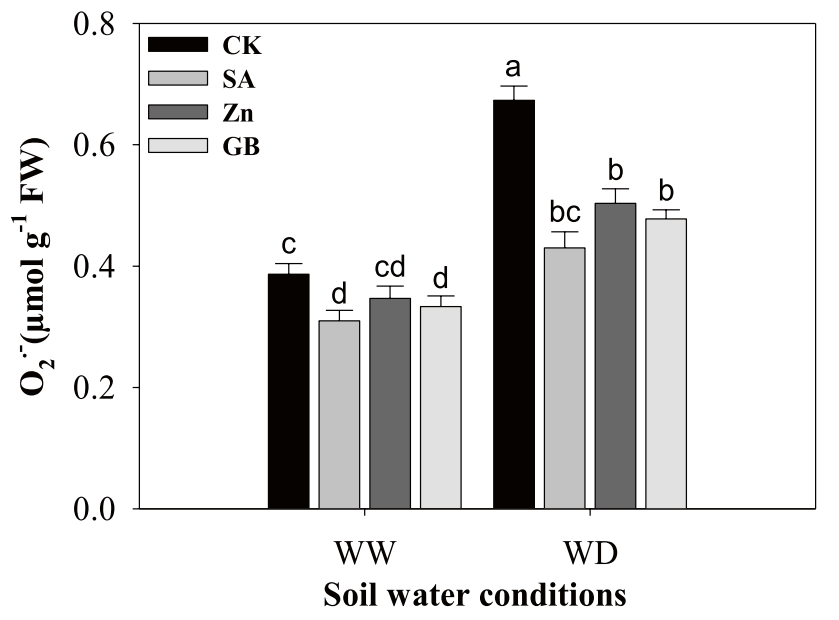

Soil water conditions

Fig. 4 Influences of soil water conditions and foliar treatments on hydrogen peroxide $\left(\mathrm{H}_{2} \mathrm{O}_{2}\right)$ and superoxide anion $\left(\mathrm{O}_{2}{ }^{-}\right)$contents. Every column in each graph represents the mean ( \pm SE) of three replicates. Various letters above columns indicate the significant differences among means $(p<0.05)$. WW, well-watered; WD, water-deficient; CK, control (double distilled water); SA, salicylic acid; Zn, zinc; GB, glycine betaine

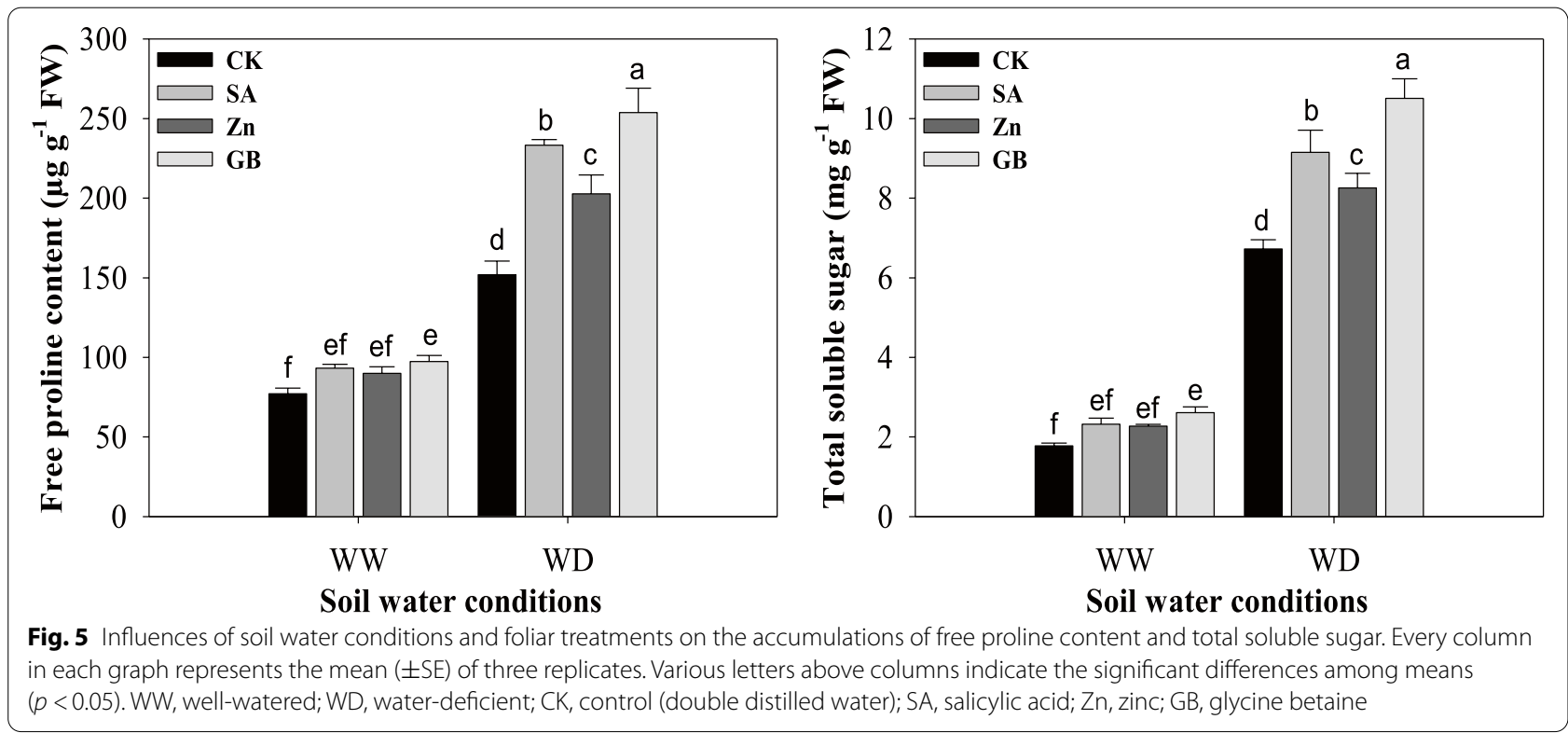

many field crops, and the reproductive growth stages are oversensitive under drought stress $[8,22,24,41$, 46]. The presented data (Tables 1, 2, and 3) indicated that water-deficient conditions statistically $(p<0.05)$ hampered wheat growth and yield parameters. However, one or more spraying treatments significantly improved growth and yield parameters except for the number of grains spike ${ }^{-1}$ compared to control treatment in both stressed and non-stressed plants. Previously, plant height and seedling fresh and dry weights were considerably decreased by water deficit, while an exogenous application with $\mathrm{GB}, \mathrm{Zn}$, and SA treatments markedly promoted maize growth [22, 25]. In this regard, Anjum et al. [37] and Raza et al. [19] revealed that growth parameters, yield, and yield attributes were statistically decreased by drought stress, while they were significantly increased by exogenous application of GB treatment in maize and wheat plants. Drought stress significantly disrupted the plant height and yield parameters in wheat [8]. Many studies indicated the applications of salicylic acid, zinc, and glycine betaine played a role to regulate protective responses under diverse stresses in many plant species $[10,22$, 24-26, 31, 35, 47]. In this study, the impairment in 
wheat growth performance and yield parameters under water-deficient conditions could be ascribed to excessive production of $\operatorname{ROS}\left(\mathrm{H}_{2} \mathrm{O}_{2}\right.$ and $\left.\mathrm{O}_{2}{ }^{\cdot-}\right)$ which led to oxidative damage to lipids membrane and raised MDA content (Figs. 3 and 4). In agreement with our results, Mittler [48] and Miller et al. [14] revealed that the increase of ROS accumulation could destroy the cell membrane and lead to immediate damage to lipids, proteins, photosynthetic pigments, nucleic acids, as well as cell structure, and finally caused the death of cells and loss of plant biomass. In contrast to the adverse impacts of the water-deficient condition, drought-tolerance induced by spraying treatments was associated with enhanced contents of Chl. a, Chl. b and total Chl., and RWC (Fig. 1), improved photosynthesis gas-exchange (Fig. 2), activities of APX, GR, POD, CAT, and SOD, and osmolytes accumulation (Figs. 3 and 5), and decreased the MDA, $\mathrm{H}_{2} \mathrm{O}_{2}$, and $\mathrm{O}_{2}{ }^{--}$contents (Figs. 3 and 4). Growth and yield increase by these exogenous applications under water-deficient conditions is an outside indicator of metabolism alteration in the plant cells. In the past, many studies have indicated the harmful effects of drought stress on the growth performance and yields of various grain crops $[10,11,22$, $46,49,50]$. However, the damage range under drought stress were differed with the strength of stresses and the crop growth stages [9].

Our results indicated that Chl. a, Chl. b, and total Chl. contents, and RWC were severely decreased in wheat plants by drought stress (Fig. 1). However, SA, Zn, and GB spraying treatments enhanced these parameters in both stressed and non-stressed plants. The decreases in photosynthetic pigments as one of the most substantial restrict factors for plant photosynthetic activity under abiotic stress were documented by numerous other studies [8, 24, 42, 51, 52]. Hussain et al. [11] found that drought stress enhanced the deterioration of chlorophyll in maize plants. In this study, photosynthetic pigments were decreased under water-deficient conditions. Previously, Anjum et al. [37] indicated that the Chl. a, Chl. $b$ and total Chl. contents in maize were reduced under progressive water deficit, while these pigments were substantially increased by GB spray application. However, RWC is a beneficial variable to assess the physiological water status of plant leaves [53]. In this regard, our previous study, Shemi et al. [22] stated that drought stress significantly reduced RWC, whilst exogenous applications with GB, Zn, and SA treatments improved the RWC under drought stress. Bayoumi et al. [45] reported that the RWC was decreased under drought stress in wheat genotypes. Likewise, drought stress at the grain filling phase substantially reduced RWC and chlorophyll content, while exogenous applications of zinc and salicylic acid had a positive impact on these parameters and alleviated the harmful effects of water deficit on wheat plants [20].

In the present study, net photosynthesis rate, transpiration rate, stomatal conductance, and intercellular $\mathrm{CO}_{2}$ concentration were considerably affected by soil water condition, while they were increased by SA, $\mathrm{Zn}$, and GB spraying treatments except for intercellular $\mathrm{CO}_{2}$ concertation (Fig. 2). Anjum et al. [37] found that the gas-exchange parameters were considerably reduced in maize cultivars under water-stressed conditions, while GB application considerably improved gas-exchange rate under water deficit as compared with control treatment. Shemi et al. [22] found that the net photosynthesis rate, transpiration, and stomatal conductance were decreased by water deficit, while exogenous application of $\mathrm{GB}, \mathrm{Zn}$, and $\mathrm{SA}$ treatments enhanced the $\mathrm{CO}_{2}$ assimilation and improved physiological water status. Under water-deficit conditions, plants tend to close the stomata, which causes reduction in $\mathrm{CO}_{2}$ availability and decrease the photosynthetic rate and finally reduces plant yield $[54,55]$. In our study, the water-deficient condition significantly increased the APX, GR, POD, CAT, and SOD activities (Fig. 3). However, the increases in activity of antioxidant enzymes were not adequate to protect against ROS accumulations and were not enough to repair the injuries of the oxidative stress triggered by the waterdeficient condition. Exogenous applications of salicylic acid, zinc, and glycine betaine to wheat plants exposed to the water-deficient condition increased the activity of these antioxidant enzymes (Fig. 3). Exogenous applications modified the enzymatic and non-enzymatic antioxidants in wheat plants under stress conditions and efficiently quench the harmful ROS (Figs. 3 and 4). In the past, several studies have noticed that antioxidant enzymes and non-enzymes activities were increased, but the contents of $\mathrm{H}_{2} \mathrm{O}_{2}, \mathrm{O}_{2}{ }^{-}$and MDA were decreased by exogenous applications of $\mathrm{Zn}, \mathrm{SA}$, or GB under drought stress in various plants [10, 19, $22,28,31,35,47,56]$. In this regard, Miller et al. [14] indicated that diverse enzymatic antioxidants could maintain the equilibrium between production and scavenging of ROS, whereas activities of these enzymes may protect the plants under stress conditions. Furthermore, the foliar application of $\mathrm{GB}, \mathrm{Zn}$, and SA treatments substantially enhanced the activity of SOD, CAT, and APX enzymes and scavenged ROS accumulation in maize [22]. The SOD enzyme is considered as the first line for protecting against ROS accumulation, which stimulates the transformation of $\mathrm{O}_{2}{ }^{\cdot-}$ to $\mathrm{O}_{2}$ and $\mathrm{H}_{2} \mathrm{O}_{2}$ [57]. The CAT enzyme stimulates the conversion of $\mathrm{H}_{2} \mathrm{O}_{2}$ to $\mathrm{H}_{2} \mathrm{O}$ and molecular oxygen, where $\mathrm{H}_{2} \mathrm{O}_{2}$ is 
considered a powerful and harmful oxidizing agent [58]. MDA is regarded as an appropriate indicator for lipid peroxidation in cell membranes [48]. The present study showed that MDA content in wheat leaves was statistically increased under the water-deficient condition and it was well associated with $\mathrm{H}_{2} \mathrm{O}_{2}$ and $\mathrm{O}_{2}{ }^{-}$ contents, while respective foliar applications decreased MDA, $\mathrm{H}_{2} \mathrm{O}_{2}$, and $\mathrm{O}_{2}{ }^{-}$contents (Figs. 3 and 4). This finding indicated that exogenous applications raised the ability of plants to cope with oxidative stresses, and therefore improved the drought-tolerance.

The presented results revealed that ROS accumulation (such as $\mathrm{H}_{2} \mathrm{O}_{2}$ and $\mathrm{O}_{2}{ }^{--}$contents) was statistically increased under the water-deficient condition and decreased by SA, Zn, and GB spraying treatments (Fig. 4). This was also proved by Wang and Jin [35], Sofy [48], Talaat et al. [6], Abdel-Motagally and El-Zohri [8], Datir et al. [17], Hasanuzzaman et al. [40] and Shemi et al. [22] who indicated ROS accumulation was considerably increased under drought stress and decreased by exogenous applications of $\mathrm{SA}, \mathrm{Zn}$, and GB in various field crops. In this regard, APX and GR are two main enzymes in the cycle of GSH-AsA, that are useful for scavenging $\mathrm{H}_{2} \mathrm{O}_{2}$ and $\mathrm{O}_{2}{ }^{\cdot-}$ in the compartments of cellular, especially in the chloroplast $[6,24,42,43]$. In this study, the activity of enzymes was usually promoted by exogenous applications of SA, Zn, and GB as compared to the control treatment. In addition to the enzymatic defense system, some compatible solutes vigorously participate in the amelioration of drought stress. Proline and soluble sugar are very important for the osmoregulation process in plants under drought stress. In this study, proline and soluble sugar in wheat leaves were enhanced under the water-deficient condition and they were also significantly increased by SA, Zn, and GB spraying applications (Fig. 5). This phenomenon can be considered as a portion of the mechanism to inhibit water loss in plants by adjusting the osmotic condition $[42,44]$. In our previous study, free proline and soluble sugar in maize were improved by SA, Zn, and GB treatments under drought stress [22]. Furthermore, Hussain et al. [11] and Abdel-Motagally and El-Zohri [8] indicated that proline content and soluble sugar were noticeably enhanced in tested plant leaves under drought stress compared to control treatments. Nasrin et al. [47] revealed that proline and soluble sugar content were significantly increased by the application of salicylic acid under different irrigation schedules. Moreover, El Tayeb and Ahmed [59] remarked that the accumulation of sugars content in shoots and roots of wheat cultivars was substantially promoted under water stress and increased by exogenous application of SA. Proline content was substantially increased under water deficit as compared to well-watered conditions in wheat genotypes [45].

As noticed in this study, all precedent results proposed that foliar applications could be regarded as protection compounds against oxidative damage caused by drought stress, which could improve the photosynthesis pigments, RWC, leaf gas-exchange, and the capacity of the antioxidant defense system, decrease the $\mathrm{MDA}, \mathrm{H}_{2} \mathrm{O}_{2}$, and $\mathrm{O}_{2}{ }^{--}$contents, and increase the osmolyte accumulation in water-stressed plants, thus they might be considered as an important strategy to improve plant growth and yield attributes under drought stress (Fig. 6).

\section{Conclusions}

The present study pointed out that the exogenous application of SA, Zn, and GB treatments could partially mitigate the harmful effects of water stress on the growth of wheat through increasing chlorophyll contents, RWC, modulating gas-exchange traits, enhancing expression of antioxidant enzymes, scavenging ROS, and increasing accumulation of osmolytes. These mechanisms are very important to sustained wheat production in comparatively water-meager regions. Among the foliar application compounds, GB was most effective followed by SA and $\mathrm{Zn}$ in promoting the growth and yield attributes of wheat. It could be concluded that exogenous GB, SA, and $\mathrm{Zn}$ applications could minimize the loss of wheat yield triggered by drought stress.

\section{Materials and methods}

\section{Experimental design and plant growth conditions}

The controlled pot experiment was conducted during the winter cultivating season of 2018-2019 at the glasshouse of the College of Agronomy and Biotechnology, Southwest University, Chongqing, China. The experimental area lies at longitude $106^{\circ} 26^{\prime} 02^{\prime \prime} \mathrm{E}$, latitude $29^{\circ}$ $49^{\prime} 32^{\prime \prime} \mathrm{N}$, and altitude $220 \mathrm{~m}$. During the cultivation season, the average minimum and maximum temperatures were 10 to $26^{\circ} \mathrm{C}$, and the relative humidity was between 75 to $87 \%$. The experiment was implemented in a completely randomized design (CRD) with two factors: two soil water conditions (well-watered condition at $85 \%$ of field capacity, and water-deficient condition at $50 \%$ of field capacity), and four spraying treatments [0.00 double distilled water (CK), $140 \mathrm{mgl}^{-1}$ salicylic acid (SA), $4 \mathrm{gl}^{-1}$ zinc ( $\mathrm{Zn}$ ), and $11.5 \mathrm{gl}^{-1}$ glycine betaine (GB)]. The effective concentrations of these spraying treatments were based on enhancements in the growth and yield of various crops under water-deficient conditions [10,19-22]. The experiment included eight treatments, and each treatment involved twelve pots. A winter wheat cultivar Yumai-13, which was bred by Sichuan Agricultural University and Chongqing 


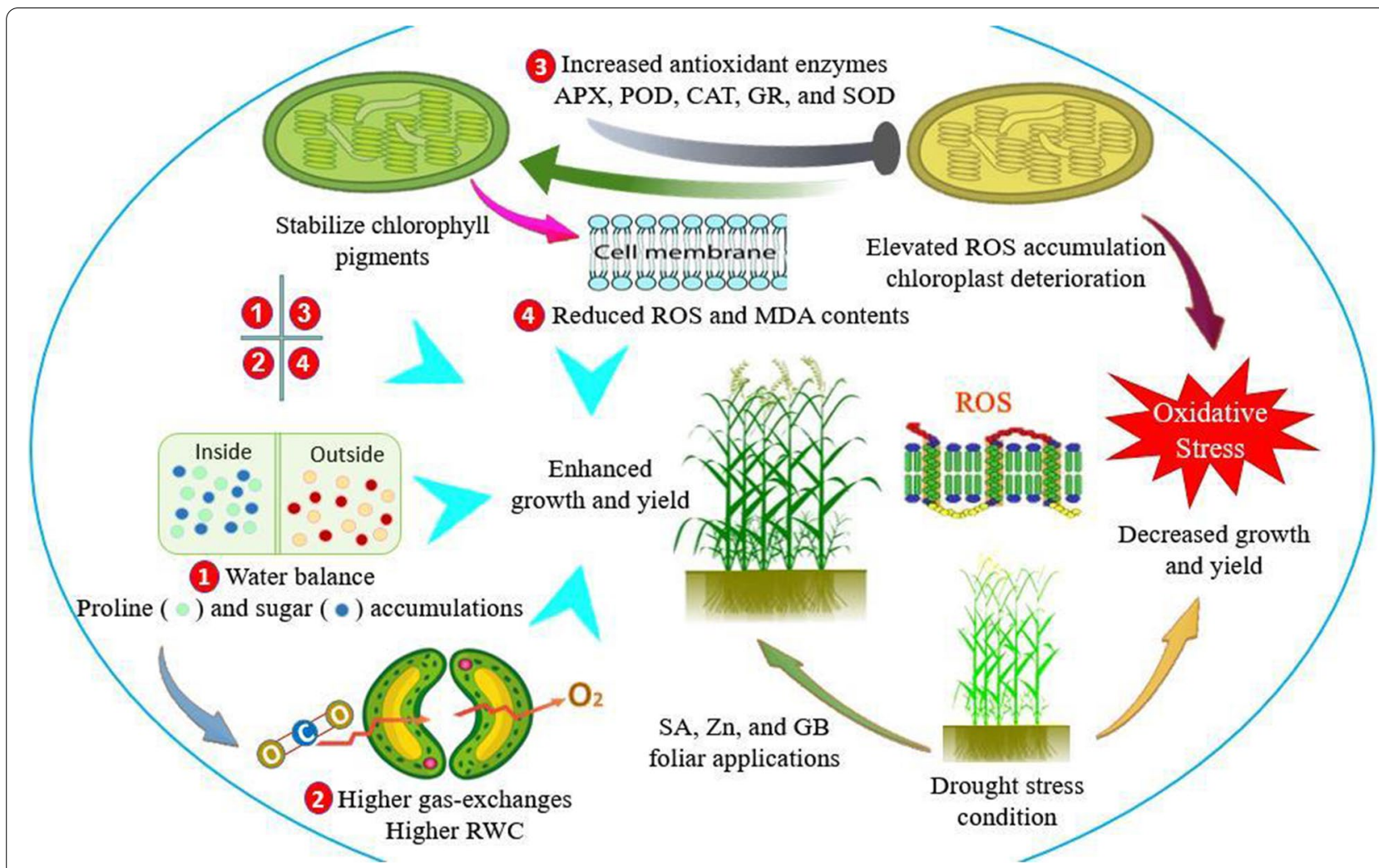

Fig. 6 The various mechanisms of foliar salicylic acid (SA), zinc ( $Z n)$ and glycine betaine (GB) treatments induced drought-tolerance in wheat plants. RWC, relative water content; APX, ascorbate peroxidase; GR, glutathione reductase; POD, peroxidase; CAT, catalase; SOD, superoxide dismutase; ROS, reactive oxygen species; MDA, malonaldehyde

Academy of Agricultural Sciences in China, was used as plant material, and the seeds were obtained from Wheat Research Institute, College of Agronomy and Biotechnology, Southwest University, Chongqing, China.

Each plastic pot $(25 \mathrm{~cm}$ diameter, $30 \mathrm{~cm}$ depth $)$ was filled with $8 \mathrm{~kg}$ air-dried and sieved $(0.5 \mathrm{~mm})$ soil, which was collected from the experimental station at the College of Agronomy and Biotechnology, Southwest University. Experimental soil was clay loam, and had the following physical and chemical properties: $\mathrm{pH}$, organic matter, electrical conductivity (EC), bulk density, soil water content at field capacity (FC), total N, available phosphorous, and available potassium were 6.25 , $12.58 \mathrm{~g} \mathrm{~kg}^{-1}, 0.45 \mathrm{ds} / \mathrm{m}, 1.44 \mathrm{~g} \mathrm{~cm}^{-3}, 24.35 \%, 0.98 \mathrm{~g} \mathrm{~kg}^{-1}$, $15.53 \mathrm{mg} \mathrm{kg}^{-1}$, and $86.11 \mathrm{mg} \mathrm{kg}^{-1}$, respectively. At the time of soil filling, $2.7 \mathrm{~g}$ controlled-release urea $(44.6 \%$ $\mathrm{N}), 3.5 \mathrm{~g}$ calcium superphosphate $\left(12 \% \mathrm{P}_{2} \mathrm{O}_{5}\right), 1.5 \mathrm{~g}$ potassium chloride $\left(60 \% \mathrm{~K}_{2} \mathrm{O}\right)$ were applied for each pot. Fifteen uniform grains were manually sown in the third week of November in pots at depth of $4-5 \mathrm{~cm}$. Thinning was conducted 10 days after germination, and seven uniform seedlings per pot were selected for the subsequent studies. Each pot was irrigated to $85 \%$ FC by tap water till the start of drought stress treatments.

\section{Soil water conditions}

The plants were subjected to two soil water conditions for 30 days, from booting (Feekes 10 stage) until milk (Feekes 11 stage) stages of wheat: well-watered condition $(85 \%$ of field capacity; WW) and water-deficient condition $(50 \%$ of field capacity; WD). During the drought period, the pots were weighed daily to keep the required soil water levels by adding proper water volumes. Soil water contents for 85 and $50 \%$ field capacity were 22.5 and $11.25 \%$, respectively [22]. Soil water content (SWC) was determined using the following equation: SWC $\%=[(\mathrm{FW}-$ $\mathrm{DW}) / \mathrm{DW}] \times 100$, where FW was the fresh weight of soil sample from the inner area of each pot, and DW was the dry weight of soil sample after oven drying at $85^{\circ} \mathrm{C}$ for 3 days [60].

\section{Spraying treatments}

After 7 and 15 days of drought treatment, the wheat plants under each water condition were sprayed with 0.00 (double distilled water; CK), $140 \mathrm{mgl}^{-1} \mathrm{SA}$ 
(hydroxybenzoic acid-2 $\mathrm{C}_{7} \mathrm{H}_{6} \mathrm{O}_{3}, \mathrm{MW}=138.12 \mathrm{~g} \mathrm{~mol}^{-1}$ ), $4 \mathrm{gl}^{-1} \mathrm{Zn}$ (zinc sulfate heptahydrate $\mathrm{ZnSO}_{4} \cdot 7 \mathrm{H}_{2} \mathrm{O}$, $\mathrm{MW}=287.54 \mathrm{~g} \mathrm{~mol}^{-1}$ ), and $11.5 \mathrm{gl}^{-1} \mathrm{~GB}$ (betaine $\mathrm{C}_{5} \mathrm{H}_{11} \mathrm{NO}_{2}, \quad \mathrm{MW}=117.14 \mathrm{~g} \mathrm{~mol}^{-1}$ ) [22]. Tween-20 $(0.05 \%)$ was added with foliar applications as a surfactant at the time of treatment.

\section{Measurements and analysis}

Wheat plants were sampled after 15 days of foliar application treatments to measure growth, photosynthetic pigments, RWC, photosynthesis gas-exchange, and biochemical assays. Completely expanded, undamaged, and healthy wheat plant leaves ( $2^{\text {nd }}$ leaf from the top) from all replicates were sampled. After washing, wheat leaves were frozen with liquid $\mathrm{N}_{2}$ immediately and stored at $-80^{\circ} \mathrm{C}$ for biochemical analyses, and analysis of yield attributes were recorded at harvesting time.

\section{Growth, yield, and its attributes}

Four pots were randomly selected and plants of each pot were taken to measure plant height, fresh weight pot $^{-1}$, dry weight pot $^{-1}$, and leaf area pot ${ }^{-1}$. Total leaf area pot $^{-1}$ was measured with LI-3100 leaf area meter (LiCOR, CID, Inc., USA). The dry weight of plants pot $^{-1}$ was estimated following oven drying at $85^{\circ} \mathrm{C}$ for $48 \mathrm{~h}$. At full maturity (plants at 160-days old), five pots were randomly selected, and plants of each pot were harvested to measure the number of tillers pot $^{-1}$, number of spikes pot $^{-1}$, number of grains spike ${ }^{-1}$, grain weight spike ${ }^{-1}$ (g), 1000-grain weight (g), biological yield pot $^{-1}(\mathrm{~g})$, grain yield $\operatorname{pot}^{-1}(\mathrm{~g})$, and harvest index (HI). The HI was computed as the percent ratio of grain yield and biological yield according to Donald [61].

\section{Photosynthetic pigments and RWC}

Chlorophyll (Chl. a, Chl. b, and total Chl.) contents were determined in the $2^{\text {nd }}$ leaf from the top according to Peng and Liu [62]. The extraction of a $200 \mathrm{mg}$ leaf blade sample was done with $10 \mathrm{ml}$ ethanol-acetone $(1: 2, \mathrm{v} / \mathrm{v})$, and the extract was moved to a $15 \mathrm{ml}$ centrifuge tube. The tubes were put in the dark to avoid light for $24 \mathrm{~h}$ until the sample changed into a white color. The chlorophyll content was calculated by the following equation: Chlorophyll a content $(\mathrm{mg} / \mathrm{g}$ tissue $)=\left(12.7 \mathrm{D}_{663}-2.69 \mathrm{D}_{645}\right) \times \mathrm{V} /$ $(1000 \times \mathrm{W})$, Chlorophyll b content $(\mathrm{mg} / \mathrm{g}$ tissue $)=(22.7$ $\left.\mathrm{D}_{645}-4.68 \mathrm{D}_{663}\right) \times \mathrm{V} /(1000 \times \mathrm{W})$, and total chlorophyll $(\mathrm{mg} / \mathrm{g}$ tissue $)=\mathrm{D}_{652} \times \mathrm{V} /(34.5 \times \mathrm{W}) /$ Chl $a+$ Chl $b$, where, $\mathrm{D}_{663}, \mathrm{D}_{645}$, and $\mathrm{D}_{652}$, respectively are the corresponding wavelengths of the light density value, $\mathrm{V}$ is the volume of extracting liquid and $\mathrm{W}$ is the weight of fresh leaf. The RWC of wheat leaves was measured according to Barrs and Weatherley [63]. Fresh leaves were cut into small segments $(1.5 \mathrm{~cm}$ length), weighed fresh weight
(FW), then floated in distilled water for $4 \mathrm{~h}$ under low light to register saturated weight (SW), and then dried in an oven until constant weight at $80^{\circ} \mathrm{C}$ for $24 \mathrm{~h}$ to record dry weight (DW). RWC was computed as: $\mathrm{RWC}=(\mathrm{FW}$ $\mathrm{DW}) /(\mathrm{SW}-\mathrm{DW}) \times 100 \%$.

\section{Photosynthesis gas-exchange}

Net photosynthesis rate, transpiration rate, stomatal conductance, and intercellular $\mathrm{CO}_{2}$ concentration were registered using a portable infrared gas analyzer-based photosynthesis system (LI-6400; LiCor, Inc., Lincoln, NE, USA) at 09:30-11:30 am from the fully expanded leaf ( $2^{\text {nd }}$ leaf from top). Air relative humidity and ambient $\mathrm{CO}_{2}$ concentrations were about $78 \%$ and $370 \mu \mathrm{mol} \mathrm{CO}$ $\mathrm{mol}^{-1}$, respectively during the collection of data.

\section{Assay of enzymatic antioxidants and lipid peroxidation}

Antioxidant enzyme activity was reported using commercial kits for glutathione reductase (GR, A111), superoxide dismutase (SOD, A500), catalase (CAT, A501), ascorbate peroxidase (APX, A304), and peroxidase (POD, A502), by following the manufacturer's instructions (Sino Best Biological Co., Ltd., China). The absorbance readings of GR, SOD, CAT, APX, and POD were detected at 340, 560, 240, 290, and $470 \mathrm{~nm}$, respectively using an ultraviolet (UV)-visible spectrophotometer, and their activities were expressed as units per fresh weight $\left(\mathrm{Ug}^{-1} \mathrm{FW}\right)$. One unit of GR activity was expressed as the amount of enzyme depleting $1 \mu \mathrm{mol} \mathrm{NADPH}$ in $1 \mathrm{~min}$, one unit of SOD activity was defined as the amount of enzyme needed to reduce the reference rate to $50 \%$ of maximum inhibition, one unit of CAT activity was measured as the amount of enzyme that decomposes $1 \mathrm{nmol}_{2} \mathrm{O}_{2}$ at $240 \mathrm{nmmin}^{-1}$ in $1 \mathrm{~g}$ fresh weight, one unit of APX was estimated as the amount of enzyme required for catalyzing $1 \mu \mathrm{mol}$ ASA at $290 \mathrm{~nm} 2 \mathrm{~min}^{-1}$ of $1 \mathrm{~g}$ fresh weight in $1 \mathrm{ml}$ of a reaction mixture, and one unit of POD activity was demonstrated as the absorbance change of 0.01 at $470 \mathrm{~nm} \mathrm{~min}^{-1}$ for $1 \mathrm{~g}$ fresh weight in $1 \mathrm{ml}$ of a reaction mixture [22]. Lipid peroxidation in wheat leaves was assayed as MDA content, and was measured by thiobarbituric (TBA) method using MDA Detection Kit (A401). Lipid hydroperoxide degradation products could condense with thiobarbituric acid (TBA) to yield red compounds [22]. The absorbance for MDA content was recorded at 532 and $600 \mathrm{~nm}$ and expressed as $\mathrm{nmol} \mathrm{g}^{-1}$ fresh weight.

\section{Determination of reactive oxygen species accumulation}

The contents of $\mathrm{H}_{2} \mathrm{O}_{2}$ and $\mathrm{O}_{2}{ }^{\cdot-}$ in the wheat leaves were noted using the commercial ' $\mathrm{H}_{2} \mathrm{O}_{2}$ Detection Kit (A400)' and ' $\mathrm{O}_{2}{ }^{-}$Detection kit (A407)', respectively, according to the manufacturer's instructions. $\mathrm{H}_{2} \mathrm{O}_{2}$ content was estimated at $415 \mathrm{~nm}$ and represented as $\mu \mathrm{mol} \mathrm{g} \mathrm{g}^{-1}$ 
fresh weight. Super oxygen anion serotonin reacted with hydrochloride to produce $\mathrm{NO}_{2}^{-}$. The $\mathrm{NO}_{2}{ }^{-}$interacted with amino benzene and alpha-pyridoxine to produce red compounds at $530 \mathrm{~nm}$ which had a characteristic absorption peak [22]. The content of $\mathrm{O}_{2}{ }^{--}$was measured at $530 \mathrm{~nm}$ and expressed as $\mu \mathrm{mol} \mathrm{g}^{-1}$ fresh weight.

\section{Estimation of osmolytes accumulation}

Proline and soluble sugar contents in wheat leaves were determined using commercial kits for proline (PRO, A605) and soluble sugar contents (SSC, B602), according to the manufacturer's instructions (Sino Best Biological Co., Ltd., China). The absorbance reading of the toluene layer was estimated at $520 \mathrm{~nm}$, on a spectrophotometer, and proline (Sigma, St Louis, MO, USA) was used for the standard curve [22]. Proline content was expressed as $\mu \mathrm{g} \mathrm{g}^{-1}$ fresh weight. The absorbance reading of SSC was detected at $620 \mathrm{~nm}$ using an ultraviolet (UV)-visible spectrophotometer [22]. Soluble sugar content was articulated as $\mathrm{mg} \mathrm{g}^{-1}$ fresh weight.

\section{Statistical analysis}

The collected data were analyzed following the analysis of variance (ANOVA) according to the Two-way Factorial Design using Statistical Software Package MSTAT-C [64]. The significant differences among mean values were estimated according to Least significant difference test (L.S.D.) at a 95\% confidence level [65]. Sigma Plot 10.0 (Systat Software Inc., San Jose, CA, USA) was used for the graphical presentation of the data.

\begin{abstract}
Abbreviations
SA: Salicylic acid; Zn: Zinc; GB: Glycine betaine; CK: Double distilled water; RWC: Relative water content; ROS: Reactive oxygen species; $\mathrm{H}_{2} \mathrm{O}_{2}$ : Hydrogen peroxide; $\mathrm{O}_{2}^{--}$: Superoxide anion radical; MDA: Malonaldehyde; GR: Glutathione reductase; SOD: Superoxide dismutase; CAT: Catalase; APX: Ascorbate peroxidase; POD: Peroxidase; PEG: Polyethylene glycol; Chl: Chlorophyll; Pn: Net photosynthesis rate; Tr: Transpiration rate; Gs: Stomatal conductance; Ci: Intercellular $\mathrm{CO}_{2}$ concentration; WW: Well-watered condition; WD: Waterdeficient condition; SWC: Soil water content.
\end{abstract}

\section{Acknowledgements \\ The present work is part of the Ph.D. dissertation of the first author. The first author gives his gratitude to the teams of Key Laboratory of Eco-environments in Three Gorges Reservoir Region, and Engineering Research Center of South Upland Agriculture, Ministry of Education, China for their help and support in the experiment; Department of Agronomy, Faculty of Agriculture, Cairo University, and Egypt for their permission and encouragement to study my Doctorate in China. We thank Mrs. Esraa Hussein for helping us to make the figures.}

\section{Authors' contributions}

R.S, L.W, and EL. Gh conceived and designed the research. R.S, R.W, H.A.H, and L.C performed the experiment. R.S wrote the initial draft of the manuscript. R.S and R.W contributed to reagents, materials, and analysis tools. R.S, EL. Gh, K.Z, $S . Z$, and L.W revised subsequent versions of the manuscript, prepared the final version, and provided technical guidance. All authors have read and approved the final manuscript.

\section{Funding}

This work was supported by the China Scholarship Council (CSC No. 2017GBJ001939)/Special Fund for Agro-Scientific Research in the Public Interest (No. 201503127) and the Natural Science Foundation Project of China (No. 31871583).

\section{Availability of data and materials}

All the data in this work is available in this manuscript and supplementary files. The data that support the findings of this study are available from the corresponding author upon reasonable request.

\section{Declarations}

Ethics approval and consent to participate

We confirm that our study does not involve human subjects.

\section{Consent for publication}

All authors agreed to publish.

\section{Competing interests}

The authors have no competing interests to declare. This work is original and has never been published before. We have no conflict with any other scientist.

\section{Author details}

${ }^{1}$ College of Agronomy and Biotechnology, Southwest University, Chongqing 400715, China. ${ }^{2}$ Department of Agronomy, Faculty of Agriculture, Cairo University, Giza 12613, Egypt. ${ }^{3}$ Institute of Environment and Sustainable Development in Agriculture, Chinese Academy of Agricultural Sciences, Beijing 100081, China.

Received: 20 September 2021 Accepted: 22 November 2021

Published online: 06 December 2021

\section{References}

1. Ibrahim MU, Khaliq A, Hussain S, Murtaza G. Sorghum water extract application mediates antioxidant defense and confers drought stress tolerance in wheat. J Plant Growth Regul. 2021:1-12. https://doi.org/10. 1007/s00344-021-10345-y.

2. Hussain S, Khaliq A, Tanveer M, Matloob A, Hussain HA. Aspirin priming circumvents the salinity-induced effects on wheat emergence and seedling growth by regulating starch metabolism and antioxidant enzyme activities. Acta Physiol Plant. 2018a;4:1-12.

3. Thind S, Hussain I, Ali S, Hussain S, Rasheed R, Ali B, et al. Physiological and biochemical bases of foliar silicon-induced alleviation of cadmium toxicity in wheat. J Soil Sci Plant Nut. 2020;4:2714-30.

4. FAOSTAT. Population data. Food and Agricultural Organization of United Nation, Roma. 2019; On line at http://Faostat.fao.org/ download/O/OA/E.

5. Daryanto S, Wang L, Jacinthe PA. Global synthesis of drought effects on maize and wheat production. PLoS One. 2016;5:e0156362.

6. Talaat NB, Shawky BT, Ibrahim AS. Alleviation of drought-induced oxidative stress in maize (Zea mays L.) plants by dual application of 24-epibrassinolide and spermine. Environ Exp Bot. 2015;113:47-58.

7. Kosová K, Urban MO, Vítámvás P, Prasil IT. Drought stress response in common wheat, durum wheat, and barley: transcriptomics, proteomics, metabolomics, physiology, and breeding for an enhanced drought tolerance. In: Hossain MA, Wani SH, Bhattacharjee S, Burritt DJ, Tran LSP, editors. Drought stress tolerance in plants: molecular and genetic perspectives, vol. 2. Switzerland: Springer International Publishing Switzerland; 2016. p. 277-314.

8. Abdel-Motagally FMF, El-Zohri M. Improvement of wheat yield grown under drought stress by boron foliar application at different growth stages. J Saudi Soc Agric Sci. 2018;2:178-85.

9. Hussain HA, Hussain S, Khaliq A, Ashraf U, Anjum SA, Men S, et al. Chilling and drought stresses in crop plants: implications, cross talk, and potential management opportunities. Front Plant Sci. 2018b;9:393. https://doi.org/ 10.3389/fpls.2018.00393.

10. Sohag AAM, Tahjib-UI-Arif M, Brestič M, Afrin S, Sakil MA, Hossain MT, et al. Exogenous salicylic acid and hydrogen peroxide attenuates drought 
stress in rice. Plant Soil Environ. 2020;66:7-13. https://doi.org/10.17221/ 472/2019-PSE.

11. Hussain HA, Men S, Hussain S, Chen Y, Ali S, Zhang S, et al. Interactive effects of drought and heat stresses on morpho-physiological attributes, yield, nutrient uptake and oxidative status in maize hybrids. Sci Rep. 2019;9(1):3890. https://doi.org/10.1038/s41598-019-40362-7.

12. Nisa W, Nisa V, Nagoo SA, Dar ZA. Drought tolerance mechanism in wheat: a review. Pharma Innovation. 2019;2:714-24.

13. Xu Q, Fu H, Zhu B, Hussain HA, Zhang K, Tian X, et al. Potassium improves drought stress tolerance in plants by affecting root morphology, root exudates and microbial diversity. Metabolites. 2021;3:131.

14. Miller G, Suzuki N, Ciftci-Yilmaz S, Mittler R. Reactive oxygen species homeostasis and signalling during drought and salinity stresses. Plant Cell Environ. 2010;33:453-67. https://doi.org/10.1111/j.1365-3040.2009. 02041.x.

15. Scheibe R, Beck E. Drought, desiccation, and oxidative stress. In: Lüttge $U$, Beck E, Bartels D, editors. Plant desiccation tolerance. Ecological studies (analysis and synthesis), vol. 215. Berlin, Heidelberg: Springer; 2011. p. 209-31.

16. Hussain HA, Men S, Hussain S, Zhang Q, Ashraf U, Anjum SA, et al. Maize tolerance against drought and chilling stresses varied with root morphology and antioxidative defense system. Plants. 2020;6:720.

17. Datir SS, Inamdar A. Biochemical responses of wheat cultivars to peginduced drought stress. Russ Agric Sci. 2019;45:5-12. https://doi.org/10. 3103/S1068367419010038.

18. Chen X, Min D, Yasir TA, Hu YG. Evaluation of 14 morphological, yieldrelated and physiological traits as indicators of drought tolerance in Chinese winter bread wheat revealed by analysis of the membership function value of drought tolerance (MFVD). Field Crops Res. 2012;137:195-201. https://doi.org/10.1016/j.fcr.2012.09.008.

19. Raza MAS, Saleem MF, Shah GM, Khan IH, Raza A. Exogenous application of glycinebetaine and potassium for improving water relations and grain yield of wheat under drought. J Soil Sci Plant Nut. 2014;2:348-64.

20. Yavas I, Unay A. Effects of zinc and salicylic acid on wheat under drought stress. J Anim Plant Sci. 2016:4:1012-8.

21. Sedaghat M, Sarvestani ZT, Emam Y, Bidgoli AM. Physiological and antioxidant responses of winter wheat cultivars to strigolactone and salicylic acid in drought. Plant Physiol Bioch. 2017;119:59-69. https://doi.org/10. 1016/j.plaphy.2017.08.015.

22. Shemi R, Wang R, Gheith ESM, Hussain HA, Hussain S, Irfan M, et al. Effects of salicylic acid, zinc and glycine betaine on morpho-physiological growth and yield of maize under drought stress. Sci Report. 2021;1:1-14.

23. Maruri-López I, Aviles-Baltazar NY, Buchala A, Serrano M. Intra and extracellular journey of the phytohormone salicylic acid. Front. Plant Sci. 2019;10:423. https://doi.org/10.3389/fpls.2019.00423.

24. Azmat A, Yasmin H, Hassan MN, Nosheen A, Naz R, Sajjad M, llyas N, Akhtar MN. Co-application of bio-fertilizer and salicylic acid improves growth, photosynthetic pigments and stress tolerance in wheat under drought stress. PeerJ. 2020;8:e9960. https://doi.org/10.7717/peerj.9960.

25. Tayyab N, Naz R, Yasmin H, Nosheen A, Keyani R, et al. Combined seed and foliar pre-treatments with exogenous methyl jasmonate and salicylic acid mitigate drought-induced stress in maize. PLoS One. 2020;15:e0232269. https://doi.org/0232210.0231371/journal.pone.02322 69.

26. Naz R, Sarfraz A, Anwar Z, et al. Combined ability of salicylic acid and spermidine to mitigate the individual and interactive effects of drought and chromium stress in maize (Zea mays L.). Plant Physiol Biochem. 2021:159:285-300.

27. Hayat $Q$, Hayat S, Irfan M, Ahmad A. Effect of exogenous salicylic acid under changing environment: A review. Environ Exp Bot. 2010;68:14-25.

28. Chen YE, Cui JM, Li GX, Yuan M, Zhang ZW, Yuan S. Effect of salicylic acid on the antioxidant system and photosystem II in wheat seedlings. Biol Plant. 2016;60:139-47.

29. Noreen S, Fatima K, Athar HUR, Ahmad S, Hussain K. Enhancement of physio-biochemical parameters of wheat through exogenous application of salicylic acid under drought stress. J Anim Plant Sci. 2017:27:153-63.

30. Fardus J, Matin MA, Hasanuzzaman M, Hossain MA, Hasanuzzaman M. Salicylic acid-induced improvement in germination and growth parameters of wheat under salinity stress. J Anim Plant Sci. 2018;1:197-207.
31. MR, Sofy. Application of salicylic acid and zinc improves wheat yield through physiological processes under different levels of irrigation intervals. Int. J Plant Res. 2015;5:136-56.

32. Sharma M, Gupta SK, Majumder B, Maurya VK, Deeba F, Alam A, et al. Salicylic acid mediated growth, physiological and proteomic responses in two wheat varieties under drought stress. J Proteome. 2017;23:28-51. https://doi.org/10.1016/j.jprot.2017.05.011.

33. Khan HR, McDonald GK, Rengel Z. Zinc fertilization and water stress affects plant water relations, stomatal conductance and osmotic adjustment in chickpea (Cicer arietinum L.). Plant Soil. 2004;267:271-84.

34. Nasiri Y, Najafi N. Effect of soil and foliar application of zinc and iron on flowering and essential oil of chamomile at green house conditions. Acta Agric Slov. 2015;105:1-4.

35. Wang $\mathrm{H}$, Jin J. Effects of zinc deficiency and drought on plant growth and metabolism of reactive oxygen species in maize (Zea mays L.). Agric Sci China. 2007:8:988-95.

36. Rahmani F, Sayfzadeh S, Jabbari H, Valadabadi SA, Masouleh EH. Alleviation of drought stress effects on safflower yield by foliar application of zinc. Int J Plant Prod. 2019;4:297-308.

37. Anjum SA, Farooq M, Wang LC, Xue LL, Wang SG, Wang L, et al. Gas exchange and chlorophyll synthesis of maize cultivars are enhanced by exogenously-applied glycinebetaine under drought conditions. Plant Soil Environ. 2011;7:326-31.

38. Marcinska I, Czyczylo-Mysza I, Skrzypek E, Filek M, Grzesiak S, Grzesiak MT, et al. Impact of osmotic stress on physiological and biochemical characteristics in drought susceptible and drought resistant wheat genotypes. Acta Physiol Plant. 2012;35:451-61.

39. Raza MAS, Saleem MF, Ashraf MY, Ali A, Asghar HN. Glycinebetaine applied under drought improved the physiological efficiency of wheat (Triticum aestivum L.) plant. Soil Environ. 2012;1:67-71.

40. Hasanuzzaman M, Banerje A, Bhuyan MHMB, Roychoudhury A, Al Mahmud J, Fujita M. Targeting glycinebetaine for abiotic stress tolerance in crop plants: physiological mechanism, molecular interaction and signaling. Phyton-Int J Exp Bot. 2019;3:185-221.

41. Anjum SA, Ashraf U, Tanveer M, Khan I, Hussain S, Shahzad B, et al. Drought induced changes in growth, osmolyte accumulation and antioxidant metabolism of three maize hybrids. Front. Plant Sci. 2017;8:69. https://doi.org/10.3389/fpls.2017.00069.

42. Hassan N, Ebeed H, Aljaarany A. Exogenous application of spermine and putrescine mitigate adversities of drought stress in wheat by protecting membranes and chloroplast ultra-structure. Physiol Mol Biol Plants. 2020;26:233-45.

43. Hassan N, El-bastawisy Z, Ebeed H, et al. Role of defense enzymes, proteins, solutes and $\Delta 1$-pyrroline-5-carboxylate synthase in wheat tolerance to drought. Rend Fis Acc Lincei. 2015;26:281-91.

44. Ebeed HT, Hassan NM, Aljarani AM. Exogenous applications of polyamines modulate drought responses in wheat through osmolytes accumulation, increasing free polyamine levels and regulation of polyamine biosynthetic genes. Plant Physiol Biochem. 2017;118:438-48.

45. Bayoumi TY, Eid MH, Metwali EM. Application of physiological and biochemical indices as a screening technique for drought tolerance in wheat genotypes. Afr J Biotechnol. 2008;7:2341-52.

46. Zhang B, Li W, Chang X, Li R, Jing R. Effects of favorable alleles for watersoluble carbohydrates at grain filling on grain weight under drought and heat stresses in wheat. PLoS One. 2014;7:e102917.

47. Nasrin R, Ali E, Jahanfar D, Soodabeh J. Salicylic acid induced changes on antioxidant capacity, pigments and grain yield of soybean genotypes in water deficit condition. J Plant Interact. 2017:1:457-64.

48. R, Mittler. Oxidative stress, antioxidants and stress tolerance. Trends Plant Sci. 2002;7:405-10.

49. Kamara AY, Menkir A, Badu-Apraku B, Ibikunle O. The influence of drought stress on growth, yield and yield components of selected maize genotypes. J Agric Sci. 2003;1:43-50.

50. Rollins JA, Habte E, Templer SE, Colby T, Schmidt J, Korff MV. Leaf proteome alterations in the context of physiological and morphological responses to drought and heat stress in barley (Hordeum vulgare L.). J Exp Bot. 2013;11:3201-12.

51. Abdelkader AF, Aronsson H, Sundqvist C. High salt-stress in wheat leaves causes retardation of chlorophyll accumulation due to a limited rate of protochlorophyllide formation. Physiol Plant. 2007;130:157-66. 
52. Wang GP, Hui Z, Li F, Zhao MR, Zhang J, Wang W. Improvement of heat and drought photosynthetic tolerance in wheat by overaccumulation of glycinebetaine. Plant Biotechnol Rep. 2010;4:213-22.

53. Kadioglu A, Saruhan N, Saglam A, Terzi R, Acet T. Exogenous salicylic acid alleviates effects of long term drought stress and delays leaf rolling by inducing antioxidant system. Plant Growth Regul. 2011;1:27-37.

54. Chaves MM, Maroco JP, Pereira JS. Understanding plant responses to drought from genes to the whole plant. Funct Plant Biol. 2003;30:239-64.

55. Oneto CD, Otegui ME, Baroli I, Beznec A, Faccio P, Bossio E, et al. Water deficit stress tolerance in maize conferred by expression of an isopentenyltransferase (IPT) gene driven by a stress-and maturation-induced promoter. J Biotechnol. 2016;20:66-77.

56. Suriyan C, Thapanee S, Chalermpol K. Glycinebetaine alleviates water deficit stress in indica rice using proline accumulation, photosynthetic efficiencies, growth performances and yield attributes. Aust J Crop Sci. 2013;2:213-8.

57. Alscher PG, Erturk N, Heath LS. Role of superoxide dismutases (SODs) in controlling oxidative stress in plants. J Exp Bot. 2002;53:1331-41.

58. K, Asada. Ascorbate peroxidase-a hydrogen peroxide-scavenging enzyme in plants. Physiol Plant. 1992;2:235-41.

59. El Tayeb MA, Ahmed NL. Response of wheat cultivars to drought and salicylic acid. Am-Euras J Agron. 2010;1:1-7.

60. Coombs J, Hall DO, Long SP, Scurlock JMO. Techniques in bioproductivity and photosynthesis. Pergamon, Oxford. 1987.

61. CM, Donald. In search of yield. J Aust Inst Agric Sci. 1962;28:171-8.

62. Peng YS, Liu E. A comparative study of methods of extracting chlorophyll. Acta Agric Univ Pekinensis. 1992;1 8:247-50.

63. Barrs HD, Weatherley PE. A re-examination of the relative turgidity technique for estimating water deficits in leaves. Aust. J Biol Sci. 1962;15:413-28.

64. University, Michigan State. MSTAT-C: Micro-computer Statistical Program, Version 2. East Lansing, USA: Michigan State University; 1990.

65. Steel RC, Torrie SH. Principles and procedures of statistics. New York, London: Mc Grauc Hill Book Company, Inc; 1997.

\section{Publisher's Note}

Springer Nature remains neutral with regard to jurisdictional claims in published maps and institutional affiliations.

Ready to submit your research? Choose BMC and benefit from:

- fast, convenient online submission

- thorough peer review by experienced researchers in your field

- rapid publication on acceptance

- support for research data, including large and complex data types

- gold Open Access which fosters wider collaboration and increased citations

- maximum visibility for your research: over 100M website views per year

At BMC, research is always in progress.

Learn more biomedcentral.com/submissions 